\title{
Social Media Adoption and its Impact on SMEs Performance A Case Study of Palestine
}

\author{
MAAN ALI ALKATEEB ${ }^{1}$, RANIA AHMAD ABDALLA ${ }^{2}$ \\ ${ }^{1}$ Industrial Management Department, Business School. PALESTINE TECHNICAL UNIVERSITY-KADOORIE. \\ PALESTINIAN. E-mail: m.khateeb@ptuk.edu.ps. \\ ORCID: http://orcid.org/0000-0002-1626-2916 \\ ${ }^{2}$ Department, Palestine Technical College. PALESTINE TECHNICAL UNIVERSITY-KADOORIE. PALESTINIAN. \\ E-mail: r.alkhateeb@ptuk.edu.ps, ORCID: http://orcid.org/0000-0001-8091-1143
}

\begin{abstract}
Many small-medium size enterprises (SMEs) are adopting social media platforms to contact their potential customers and provide their services. The impact of this adoption on the SME's performance has been roughly examined by researchers in the Middle East region particularly Palestine. Constructs and variables of three models (TOE, TAM, TPB) were used as potential predictors of social media adoption including technological, organizational, environmental context, perceived ease of use, perceived usefulness, attitude toward technology, and capability to control technology. Furthermore, the influence of this adoption on SMEs performance was also tested. A closed question questionnaire was used to gather the data, and simple regression analysis was used to examine the hypotheses. Findings revealed that all of the seven independent construct/variables except the technological context positively influence SME's adoption of social media, and social media adoption in turn positively influence SME's performance. The findings may be beneficial to SMEs's managers and the authorities as well to facilitate the use of social media by SMEs.
\end{abstract}

Keywords: Social Media adoption, SME's, SME's Performance, Palestine.

JEL Classification: L25, L81, M54, O32 


\title{
Adopción de los Medios Sociales y su Impacto en el Rendimiento de las PYME Un Estudio de Caso de Palestina
}

\author{
MAAN ALI ALKATEEB ${ }^{1}$, RANIA AHMAD ABDALLA ${ }^{2}$ \\ ${ }^{1}$ Industrial Management Department, Business School. PALESTINE TECHNICAL UNIVERSITY-KADOORIE. \\ PALESTINIAN. E-mail: m.khateeb@ptuk.edu.ps. \\ ORCID: http://orcid.org/0000-0002-1626-2916 \\ 2Department, Palestine Technical College. PALESTINE TECHNICAL UNIVERSITY-KADOORIE. PALESTINIAN. \\ E-mail: r.alkhateeb@ptuk.edu.ps, ORCID: http://orcid.org/0000-0001-8091-1143
}

\section{RESUMEN}

Muchas pequeñas y medianas empresas (PYMES) están adoptando las plataformas de los medios sociales para contactar con sus clientes potenciales y ofrecer sus servicios. Los investigadores de la región de Oriente Medio, en particular de Palestina, han examinado a grandes rasgos el impacto de esta adopción en el rendimiento de las PYME. Se utilizaron constructos y variables de tres modelos (TOE, TAM, TPB) como predictores potenciales de la adopción de los medios sociales, incluyendo el contexto tecnológico, organizativo y ambiental, la facilidad de uso percibida, la utilidad percibida, la actitud hacia la tecnología y la capacidad de control de la tecnología. Además, se comprobó la influencia de esta adopción en el rendimiento de las PYMES. Se utilizó un cuestionario de preguntas cerradas para recopilar los datos, y un análisis de regresión simple para examinar las hipótesis. Los resultados revelaron que los siete constructos/variables independientes, excepto el contexto tecnológico, influyen positivamente en la adopción de medios sociales por parte de las PYME, y que la adopción de medios sociales influye a su vez positivamente en el rendimiento de las PYME. Los resultados pueden ser beneficiosos para los gestores de las PYME y las autoridades para facilitar el uso de los medios sociales por parte de las PYME.

Palabras claves: Adopción de los medios sociales, PYME, Rendimiento de las PYME, Palestina.

Clasificación JEL: L25,L81,M54,032 


\section{Introduction}

The nature of business and the environment in which small-medium enterprises work is changing dramatically, thus requiring the need for conducting updated research to help them to response effectively to these changes (Namankani, Moxham, \& Tickle, 2016). One of the most important challenges is to use the social media to maintain high level of productivity and improve performance.

Today, small and medium enterprises (SMEs) are acknowledged as the main driver for economic growth worldwide (Salam \&Hoque, 2019). SMEs play a vital role in creating job opportunities and provide production and supporting base for large firms (Namankani, Moxham, \& Tickle, 2016). Additionally, innovation and social cohesion are another significant features of SMEs (Salam Hoque, 2019). Subsequently, they enable them to compete rivals domestically and in the international markets. In Palestinian context, SMEs are considered as the engine of socio-economic development through creating jobs, decreasing poverty, and increasing production capacity (Alfoqahaa, 2018). According to Palestinian central bureau of statistics 2015, the total number of SMEs in West Bank and Gaza strip was 135,880 presenting $96 \%$ of total businesses and employing 416,077 workers. These SMEs are working in different sectors such as industrial, agricultural, services and constructions. However, SMEs contribute less than $20 \%$ of the GDP. This might be attributed to the lack of adequate resources, inappropriate marketing strategy and poor communication with stakeholders (Hoque, Awang, \&Gwadabe, 2018). Yasa, Dnyani, \&Rahmayanti (2020) classified the reasons responsible for the fall of SMEs performance into two categories (internal and external). External factors are out of the control, while internal factors are under the control of businesses. One of the most important internal factors that has prevailed in the last two decades is the way the business communicate with stakeholders and in particular clients. In recent years more and more companies use social media in conducting their business activities. Information technology(IT) and the use of social media in particular may enables businesses to perform better in the market place (AlSharji, Ahmad, \& Bakar, 2018). It provides several benefits to SMEs such as penetrating new markets, promoting new products, building relationships with new partners (Talukder, Quazi, \&Djatikusumo, 2013). There is more evidence that small-medium enterprises must use social media to gain competitive advantage (Dahnil, Marzuki, Langgat, \&Fabeil, 2014). Social media has become a great platform for firms to manage the relational activities (Kaplan and Haenlein, 2010) and have changed the modes of all aspects of business including operations, marketing, human resource management and finance (Guha, Harrigan\&Soutar, 2018). Because of the opportunities that social media provides to business such as cost effectiveness, time saving, low level of IT skills required to use it, and the high level of engagement with customers, SMEs began to take advantage of it as a marketing tool (Abed, 2020; Öztamur\&Karakadılar, 2014). In addition, research suggests that social media creates benefits to customers (Hansson, Wrangmo\&Søilen, 2013). Thus, it is clear that SMEs could gain from social media to improve business performance. Although, several studies investigated social media use in business context, very few studies examined the impact of adoption of social media on the performance of SMEs in the Middle East (Ahmad, Bakar \& Ahmad, 2019) and specially in Palestine. Using social media by SMEs in Palestine has become a must with 2.7 Million Internet users in Jan 2020 as published by datareportal website (w1) Unfortunately, the number of SMEs that are using social media in their business in Palestine are not available; therefore, it is important to understand how social media adversely affects the performance of SMEs. there is a research gap in explaining the relationship between the use of social media and business performance.

The aim of this article is to explore those factors that might influence the adoption of social media by SMEs and its influence on performance. The article will address this issue by conducting a survey on the observed variables that reflect the attitudes of managers of SMEs. The results are expected to contribute in our understanding of how the use of social media may improve the performance of SMEs in Palestine context. 


\section{Literature review and hypothesis development}

With the short period since the social media has been started to be used by SMEs in their various activities, it has become a strategic tool for survival (Öztamur\&Karakadılar ,2014). Reviewing the literature, shows that many studies used technology adoption theories and frameworks to assess various effects on businesses with more focus on internal factors as main contributors that affect the adoption of social media. Dahnil, Marzuki, Langgat, \&Fabeil (2014) argued that it is vital for SMEs to include both internal and external factors as antecedents of social media adoption. Ordanini (2006) indicated that three basic models were used to examine the antecedents of IT adoption in large and small businesses. The first model is the Technology-Organization Environment (TOE). This model contains three main predictors of IT adoption (the technology context, the organizational context, the environmental context). The second model is the Technology Acceptance Model (TAM). This model concentrated on three elements of IT adoption (ease of use, the usefulness, and the attitudes of decisions maker). The third model is the Theory of Planned Behavior (TPB). The model contains three predictors (attitude toward change, social pressure, and the capability to control technology). Although these models are widely used by researcher, it is worth noting that these model were developed to investigate the IT adoption preceding those related to internet. Thus, it is preferable to use a hybrid model that captures different parameters of the various models. This study combined different elements of each of the previous models (Abdullatif et al 2017).

\subsection{Antecedents of social media adoption}

\subsubsection{The technological context}

The technological context is considered to have a great influence on SMEs adoption of IT including social media (Ramdani, Chevers, \& Williams, 2013). The technological context includes, the relative advantage, complexity, and compatibility (AlBar\&Hoque, 2019). Relative advantage is defined as "the degree to which an innovation is perceived as being better than the idea it supersedes" (Rogers, 2010, p. 42). It reveals the benefits or losses a firm will achieve when it accepts or rejects a technology (AlBar\&Hoque, 2019). Several studies found a positive impact of relative advantage on SMEs adoption of social media. Using an extended model of TOE to examine the impact of the model dimensions on the adoption of ICTs among SMEs in rural areas of Saudi Arabia AlBar\&Hoque (2019) found that relative advantages had a significant relationship with ICT adoption among SMEs. Similarly, Ahani, Rahim, \&Nilashi (2017) supported these findings. the results of their study revealed that relative advantage is the most important factor influencing social IT adoption. Utilizing social media enables SMEs to respond to customers anytime and anywhere. Thus, the relative advantage is a critical factor for SMEs to make a decision regarding social IT adoption. Social media technology is a cost-effective tool that can be used by SMEs to manage their activities at a low cost (Ainin et al., 2015). In contrast to these findings and in one of the very few studies that have been conducted in the Middle East countries Ahmad, Bakar, \& Ahmad (2019) noted that relative advantage had no significant relationship with social media adoption. Compatibility is defined as "the degree to which an innovation is perceived as consistent with the existing values, past experiences, and needs of potential adopters" (Rogers, 2010, p. 42). Premkumar (2003) claimed that compatibility is one of the most important factor that impacts the adoption of ICT by SMEs. Ramdani, Chevers, \& Williams (2013) found a significant positive impact of compatibility on ICT adoption in SMEs context. The same results were found by (Ahani, Rahim, \&Nilashi ,2017). Conversely, AlBar\&Hoque (2019) did not find any significant relationship between compatibility and ICT adoption by SMEs.

Complexity is defined as "the degree to which an innovation is perceived as relatively difficult to understand and to use" (Rogers, 2010, p. 42). It is believed that complexity of innovation is negatively related to ICT adoption. Low, Chen, \& Wu (2011) argued that the complexity of new technology reduces the opportunity to adopt it. The concept of complexity is a crucial technological factor that must not be neglected in technology and innovation adoption. Using social media technology enables SMEs to manage their activities. Therefore, it is interesting to identify how the complexity of social 
media, as an example of a new IT-based strategy, can be critical in SMEs' adoption decision (Ahani, Rahim, \&Nilashi ,2017).

Based on the above discussion the first suggested hypothesis is:

H1: Technological context has a high impact on SMEs' adoption of social media.

\subsubsection{The organizational context}

Like technological context, the organizational context is claimed to have a positive influence on SMEs' adoption of ICT (Ramadi, Chevers, \& Williams, 2013). Previous studies identified a set of organizational factors that have an impact on the adoption of social media by organizations. Among these factors are top management support (Ramadi et al, 2013; Ahani et al, 2017; AlBar, \&Hoque, 2019). Firm size (Wamba\& Carter, 2016; Ramadi et al, 2013; Ahmad, et al., 2019), and organizational readiness (Ramadi et al, 2013). AlSharji Ahmad, \& Bakar (2018) defined organizational characteristics as all feature of the organization including managerial structure, level of centralization, number of employees, turnover, and its resources. However, they claimed that the only salient factor is top management support. In this study, only this factor will be taken to represent the organizational context. Several studies have confirmed the positive impact of management support on organizations' intention to adopt new technology (Ahmad, et al, 2019; AlBar, \&Hoque 2019; Ahani, Rahim, \&Nilashi, 2017; Ramadi et al, 2013). AlBar\&Hoque (2019) claimed that top management support, especially in SMEs is crucial in the Arab World, where the roles of top manager are more important. Consequently, the second hypothesis is:

H2: Organizational context has a high impact on SMEs' adoption of social media.

\subsubsection{The environmental context}

According to the TOE model the environmental context refers to the conditions in which the organization conducts its business (Ahani et al., 2017). Factors that are mostly considered in previous studies include regularity system and competitive pressure (AlBar\&Hoque 2019; Ahmad et al., 2019; Ahani et al., 2017; Ramadi et al., 2013). Ahani et al. (2017) confirmed that competitive pressure had a significant influence on the decision to adopt social media, and that competitors use social media to improve their competitive advantage, to enhance the level of satisfaction of their costumers and achieve financial benefits. Lin (2014) emphasized the positive relationship between competitive pressure and intention to adopt social media, and that competition leads to high level of environmental uncertainty which in turn increases the need to adopt of IT innovation and the speed of adoption. Unlikely, Ahmad, \& Bakar (2018) found no significant influence of competitive pressure on adoption of social media. Regarding regularity system, AlBar\&Hoque (2019) argued that the government regulation provides sufficient protection for the use of ICT by SMEs, and it facilitates or hinders the enterprises to adopt new technology. Dahnil, Marzuki, Langgat, \&Fabeil (2014) indicated that government influence, policy and initiatives influence the ICT adoption. Thus, it is obvious that the legislatory environment can either support technology innovation by introducing regulations that encourage firms to adopt new technology or adversely restrict the using of new technology by passing constraining regulations (Borgman, Bahli, Heier, \& Schewski (2013). Two factors will be adopted to present the environmental context including competitive pressures and governmental legislations. Consequently, the third hypothesis is:

H3: Environmental context has a high impact on SMEs' adoption of social media.

\subsubsection{Perceived usefulness and perceived ease of use}

The TAM conceptualizes that perceived ease of use of technology and perceived usefulness predict the attention and the adoption of new technology (Siamagka, Christodoulides, Michaelidou \& Valvi, 2015). Ease of use is defined as "as the degree to which a person believes that using the system will be free of mental effort" While perceived usefulness is defined as "the degree to which a person believes 
that using a particular system would enhance his or her job performance" Davis (1989, p. 320). Venkatesh, Morris, Davis, and Davis (2003) argued that perceived usefulness and perceived ease of use are the most significant predictors of technology adoption. Awa, Ojiabo\&Emecheta, (2015) Concluded that the individual's intention to use new application is most likely to be explained and predicted by his perception of the usefulness and the simplicity of using this new technology. Ease of use was found to be one of the main determinants of ICT adoption at all stages of adoption (Eze, Chinedu-Eze, \& Bello, 2019). The influence of both perceived of usefulness and perceived ease of use can be extended to include social media adoption. Thus the following hypotheses are formulated:

H4: Perceived usefulness has a high impact on SMEs' adoption of social media.

H5: Perceived ease of use has a high impact on SMEs' adoption of social media.

\subsubsection{Attitude toward technology adoption and capability to controltechnology}

The theory of planned behaviour (TPB), extended from the theory of reasoned action (TRA) (Fishbein\&Azjen, 1975) was used to predict the behavior in general. Based on this theory the individuals' intention is the most important predictor of behavior and the intention is predicted by the attitude towards the behavior, subjective norm, and perceived behavioral control. Prior research did not support the influence of subjective norm (social pressure) on the behavioral intention, therefore this variable was excluded in this study. Attitude toward IT adoption refers to a person's beliefs towards the expectations of outcomes regarding the IT used, while perceived behavioral control refers to ones belief on the degree of usage capability of the technology (Ooi, Sim, Yew, \& Lin, 2011).

In IT context the theory was utilized to predict the determinants of IT adoption. For instance, Baker \& White (2010) used these factors to predict the intention to use the social networking sites. The results showed the positive influence of the standard TPB variables on the intention to use social networking sites. Li, Troutt, Brandyberry, \& Wang (2011) indicated that the SME owners' intention to adopt IT is determined by the attitude of the owner. It seems that people are unlikely to have intention to perform a specific behavior if they do not have the resources and the ability to do so, even if they have the positive attitudes toward that behavior (Qureshi, \& York, 2008).

Based on the above arguments the following hypotheses are formulated:

H6: The positive attitudes of the owner of SMEs towards social media is positively influencing the adoption of social media by SMEs.

H7: The ability of the owner of SMEs to control social media application is positively influencing the adoption of social media by SMEs.

\subsection{Social media adoption and business performance}

Business performance refers to the benefits that business might receive as a result of using social media in terms of both financial and non-financial performance (Delone, \& McLean, 2003).

Previous studies have investigated the antecedents of social media adoption, but few studies investigated the impact of social media adoption on business performance (Ainin et al, 2015). For instance, Yasa, Adnyani, \&Rahmayanti, (2020) provided evidence that the usage of social media by SMEs has a significant and positive influence on business performance. Ainin et al. (2015) demonstrated that the use of social media positively impacts both the financial and non-financial of SMEs performance. Similarly (Qalati, Yuan, Khan, \& Anwar, 2021) confirmed the positive relationship between the usage of social media and the performance of SMEs. Consequently, the following hypotheses are formulated:

H8: Social media adoption will have positive impact on the performance of SMEs.

Figure 1 illustrates the proposed research model. 
Figure 1. Research Model

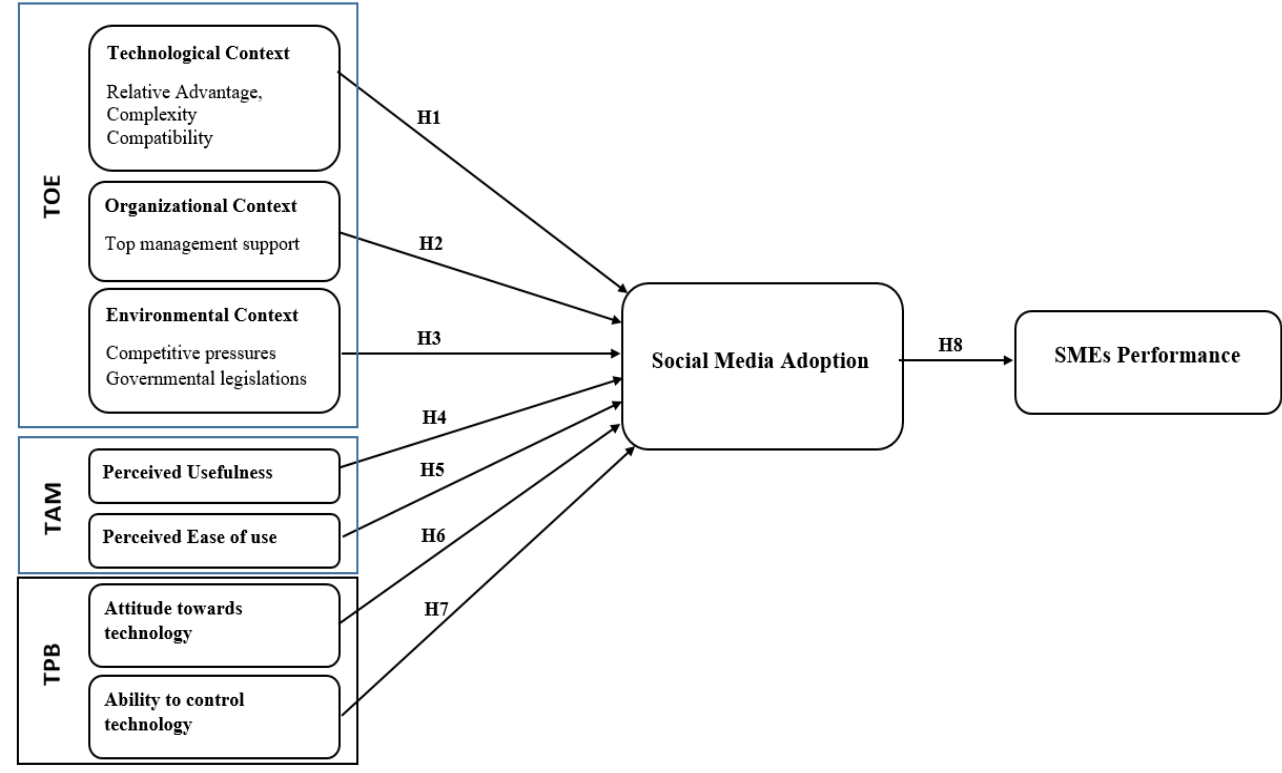

Source Prepared by the researchers

\section{Materials and Methods}

The current study aims to examine the influence of seven independent constructs/variables on social media adoption, and the impact of this adoption on SME's performance. The included constructs/variables were suggested based on the conducted literature review. The study is of an explanatory nature, thus, the researcher adopted the questionnaire approach to gather the required data from the study population.

\subsection{Study population and sample}

For the purpose of this study, enterprises that employ less than 25 workers are included in the study sample. This definition is adopted by local banks and Palestinian Monetary Authority. The study population is the SME's in Tulkarm district. According to the general census of population, housing and establishments report issued by The Palestinian Central Bureau of Statistics (2018), the number of the working SME's in Tulkarm district is 7407 enterprises. The sample size that be drawn from the population is 365 (Daneil \& Cross, 2013) at a significance level of $5 \%$.

Online survey of 500 were sent to the potential participants of SMEs operating in Tulkarm district. The e-mail of each participant was extracted from the website of chamber of commerce of each district. The targeted participants are mainly the owners or the CEOs since they are the most knowledgeable about their firms. In total 332 of completed questionnaires were received with a response rate of $66.4 \%$. This response rate is considered acceptable compared to the standard rate suggested by Curran and Blackburn (2001).

\subsection{Measurements}

All of the measure items used in this study were borrowed from previously validated scales and modified to fit the current study. All variables representing the latent variables are shown in Table 1. Each variable is measured on a five-point Likert scale ranging from 5 (strongly agree) to 1 (strongly disagree). 
Table 1: Measurement Items

\begin{tabular}{|c|c|c|}
\hline Variable & Items & Source \\
\hline $\begin{array}{l}\text { Relative } \\
\text { advantage }\end{array}$ & $\begin{array}{l}\text { - Using social media provides accurate information for } \\
\text { decision making in timely manner } \\
\text { - Using social media offers efficient way for managing } \\
\text { product and services. } \\
\text { - Using social media helps quick data capture and analysis. } \\
\text { - Using social media helps reduce inventory costs }\end{array}$ & Chong \& Chan (2012) \\
\hline Complexity & $\begin{array}{l}\text { - Using social media takes too much time from my normal } \\
\text { duties. } \\
\text { - Working with social media is so complicated, it is difficult } \\
\text { to understand what is going on } \\
\text { - Using social media involves too much time doing } \\
\text { mechanical operation (i,e data input). } \\
\text { - It takes too long to learn how to use social media to } \\
\text { make it worth the effort }\end{array}$ & $\begin{array}{l}\text { Venkatesh et al., } \\
\qquad(2003)\end{array}$ \\
\hline Compatibility & $\begin{array}{l}\text { - Using social media is compatible with existing IT } \\
\text { infrastructure } \\
\text { - Using social media is compatible with our business } \\
\text { processes and } \\
\text { - Operations } \\
\text { - It is easy to integrate social media use with our existing } \\
\text { systems }\end{array}$ & Chong \& Chan (2012) \\
\hline $\begin{array}{l}\text { Top } \\
\text { management } \\
\text { support }\end{array}$ & $\begin{array}{l}\text { - Top management in my organization is interested in } \\
\text { adopting social media } \\
\text { - Top management in my organization considers social } \\
\text { media adoption important } \\
\text { - Top management in my organization has shown support } \\
\text { for social media adoption }\end{array}$ & Ahmad et al. (2019) \\
\hline $\begin{array}{l}\text { Competitive } \\
\text { pressures }\end{array}$ & $\begin{array}{l}\text { - Social media use allows stronger competitive advantage } \\
\text { - Social media would increase ability to outperform } \\
\text { competition } \\
\text { - Social media would allow generation of higherprofits }\end{array}$ & $\begin{array}{l}\text { Oliveira et al. (2014); } \\
\text { Alshamaila et al. } \\
\text { (2013); Low et } \\
\text { al.(2011) }\end{array}$ \\
\hline $\begin{array}{l}\text { Governmental } \\
\text { legislations }\end{array}$ & $\begin{array}{l}\text { - I know that the government has policies and initiatives } \\
\text { encouraging companies to adopt social media } \\
\text { technologies } \\
\text { - I am aware of the existence of governmental agencies } \\
\text { providing services toward social media adoption }\end{array}$ & $\begin{array}{l}\text { Sophonthummapharn } \\
\text { (2009) }\end{array}$ \\
\hline $\begin{array}{l}\text { Perceived } \\
\text { ease of use }\end{array}$ & $\begin{array}{l}\text { - It is easy to access social media platforms to do what I } \\
\text { want } \\
\text { - Interacting with social media platforms is easy } \\
\text { - It's easy for me to remember how to do the tasks using } \\
\text { social media platforms } \\
\text { - Overall, I find social media platforms easy to use }\end{array}$ & Davis (1989) \\
\hline
\end{tabular}




\begin{tabular}{|c|c|c|}
\hline $\begin{array}{l}\text { Perceived } \\
\text { usefulness }\end{array}$ & $\begin{array}{l}\text { - Using social media platforms gives me more control over } \\
\text { my work } \\
\text { - Social media platforms allow me to get things done more } \\
\text { quickly } \\
\text { - Social media platforms support critical aspects of my } \\
\text { work, such as crisis } \\
\text { - Overall, I find social media platforms helpful in my work }\end{array}$ & Davis (1989) \\
\hline $\begin{array}{l}\text { Attitude } \\
\text { towards } \\
\text { technology }\end{array}$ & $\begin{array}{l}\text { - Using social media is a bad/good idea } \\
\text { - Social media use makes work more interesting } \\
\text { - Working with social media is fun } \\
\text { - I like working with social media }\end{array}$ & $\begin{array}{l}\text { Venkatesh et al. } \\
\text { (2003) }\end{array}$ \\
\hline $\begin{array}{l}\text { Ability to } \\
\text { control } \\
\text { technology }\end{array}$ & $\begin{array}{l}\text { - I have the power to control the use of social media } \\
\text { platforms } \\
\text { - I have the resources to use social media platforms } \\
\text { - I have the knowledge to use social media platforms } \\
\text { effectively }\end{array}$ & $\begin{array}{l}\text { Venkatesh et al., } \\
\text { (2003) }\end{array}$ \\
\hline $\begin{array}{l}\text { Adoption of } \\
\text { social media }\end{array}$ & $\begin{array}{l}\text { - Assuming I had access to the internet, I would have } \\
\text { already used social media } \\
\text { - I am likely to use social media } \\
\text { - Overall, I intend to continue using social media in the } \\
\text { future }\end{array}$ & $\begin{array}{c}\text { Zhu, Sangwan, \& Lu } \\
\text { (2010) }\end{array}$ \\
\hline Performance & $\begin{array}{l}\text { - The use of social media platforms increased the } \\
\text { company's market share } \\
\text { - The use of social media platforms increased the sales } \\
\text { process } \\
\text { - The use of social media platforms increased the sales } \\
\text { volume } \\
\text { - The use of social media platforms led to an increase in } \\
\text { audience inquiries } \\
\text { - The use of social media platforms increased the number } \\
\text { of customers } \\
\text { - The use of social media platforms helped achieve the } \\
\text { goals of the organization } \\
\text { - The use of social media platforms helped increase your } \\
\text { total income }\end{array}$ & $\begin{array}{l}\text { Kim, Li and Brymer } \\
\text { (2016); } \\
\text { Watson (2012); } \\
\text { Yu, Ramanathan \& } \\
\text { Nath (2014) }\end{array}$ \\
\hline
\end{tabular}

Source: Prepared by the researchers based on literatura review

\subsection{Reliability}

The reliability of the study items was tested using Cronbach Alpha Coefficient as shown in Table 2. All values were above the cutoff value of 0.7 determined by (Nunnaly, 1978) as the acceptance measure for reliability. 
Table 2: Cronbach Alpha Coefficients

\begin{tabular}{|l|c|c|c|}
\hline Variable & Mean & $\begin{array}{l}\text { Standard } \\
\text { Deviation }\end{array}$ & $\begin{array}{l}\text { Cronbach Alpha } \\
\text { Coefficient }\end{array}$ \\
\hline Relative Advantage & 3.84 & 0.598 & 0.765 \\
\hline Complexity & 3.71 & 0.887 & 0.909 \\
\hline Compatibility & 3.97 & 0.528 & 0.856 \\
\hline Top Management Support & 3.97 & 0.493 & 0.862 \\
\hline Competitive Pressures & 3.98 & 0.492 & 0.873 \\
\hline Governmental Legislations & 3.89 & 0.572 & 0.817 \\
\hline Perceived Usefulness & 3.94 & 0.488 & 0.885 \\
\hline Perceived Ease of Use & 4.05 & 0.497 & 0.861 \\
\hline Attitude towards Technology & 3.96 & 0.498 & 0.778 \\
\hline Ability to Control Technology & 4.07 & 0.543 & 0.879 \\
\hline Social Media Adoption & 4.02 & 0.523 & 0.876 \\
\hline SMEs Performance & 4.04 & 0.414 & 0.881 \\
\hline Total & \multicolumn{3}{|l}{} \\
\hline
\end{tabular}

Source: developed by the researchers based on statistical analysis

As for hypothesis testing, linear regression was used to examine the proposed hypotheses.

\section{Results}

\subsection{Demographic profile}

The demographic profile of the participants of the study is presented in Table 3. The majority of the population sample was males forming $75.9 \%$ against $24.1 \%$ females. Regarding age, $67.1 \%$ of the respondents were under 40 year old, followed by $22.6 \%$ between 40 to 49 years, and only $10.2 \%$ were above or equal 50 years, this reflect that the majority are relatively young. Concerning educational level, about $64.4 \%$ were Diploma and Bachelor degree holders, High school degree holders formed $27.4 \%$, Postgraduate degree holders were only $4.5 \%$, and only $3.3 \%$ held less than high school certificate. Relating to business age, about $34.9 \%$ of the surveyed businesses were relatively new businesses as their age was 1-3 years old, followed by $30.1 \%$ in the age group of 4-6 years old, older businesses with an age of 6 years or more formed $28.6 \%$, and last came the fresh businesses with less than one year with a percentage of $6.3 \%$.

As for the total employee number, the majority of the businesses (47.6\%) employed less than five employees, and only $7.8 \%$ employed between $21-25$ employees. Wholesale and retail trade formed $28.9 \%$ of the study sample, next were the Technical services businesses with $24.1 \%$, Entertainment services $17.2 \%$, Transport 6\%, Manufacturing industries $4.8 \%$, Restaurants $4.2 \%$, Constructions $1.8 \%$ and other industries $13 \%$. The duration of use of social media varied among the surveyed businesses. About $40.7 \%$ of the businesses have been using it for $4-6$ years, followed by $30 \%$ of the businesses with 1-3 years of usage, next came those businesses that have been using it for more than six years forming $16.6 \%$, and last came the new users of social media with less than one year of usage forming $4.8 \%$. The last demographic variable was the used social platforms. Facebook dominated the scene with $41.3 \%$, Twitter and Insagram had almost equal values with $10.8 \%$ and $10.2 \%$ respectively. $13.3 \%$ of the businesses used other platforms, and $24.4 \%$ used more than one platform. 
Table 3: Participants' demographic profile

\begin{tabular}{|c|c|c|c|}
\hline Demographic Category & Classification & Frequency & Percent \% \\
\hline \multirow{3}{*}{ Gender } & Male & 252 & 75.9 \\
\hline & Female & 80 & 24.1 \\
\hline & Total & 332 & 100 \\
\hline \multirow{5}{*}{ Age } & 20-29 Years & 105 & 31.6 \\
\hline & 30-39 Years & 118 & 35.5 \\
\hline & 40-49 Years & 75 & 22.6 \\
\hline & $>=50$ Years & 34 & 10.2 \\
\hline & Total & 332 & 100 \\
\hline \multirow{6}{*}{ Educational Level } & Less than high school & 11 & 3.3 \\
\hline & High School & 92 & 27.7 \\
\hline & Diploma & 108 & 32.5 \\
\hline & Bachelor & 106 & 31.9 \\
\hline & Post Graduate Studies & 15 & 4.5 \\
\hline & Total & 332 & 100 \\
\hline \multirow{5}{*}{ Business Age } & Less than one year & 21 & 6.3 \\
\hline & 1-3 Years & 116 & 34.9 \\
\hline & 4-6 Years & 100 & 30.1 \\
\hline & More than 6 Years & 95 & 28.6 \\
\hline & Total & 332 & 100 \\
\hline \multirow{6}{*}{ Total Employee Number } & Less than 5 employees & 158 & 47.6 \\
\hline & 5-10 employees & 61 & 18.4 \\
\hline & 11-15 employees & 67 & 20.2 \\
\hline & 16-20 employees & 20 & 6.0 \\
\hline & 21-25 employees & 26 & 7.8 \\
\hline & Total & 332 & 100 \\
\hline \multirow{9}{*}{ Sector } & $\begin{array}{l}\text { Manufacturing } \\
\text { industries }\end{array}$ & 16 & 4.8 \\
\hline & Constructions & 6 & 1.8 \\
\hline & $\begin{array}{l}\text { Wholesale and retail } \\
\text { trade }\end{array}$ & 96 & 28.9 \\
\hline & Transport & 20 & 6.0 \\
\hline & Technical services & 80 & 24.1 \\
\hline & Restaurants & 14 & 4.2 \\
\hline & Entertainment services & 57 & 17.2 \\
\hline & Others & 43 & 13.0 \\
\hline & Total & 332 & 100 \\
\hline \multirow{5}{*}{ Duration of Use } & Less than one year & 16 & 4.8 \\
\hline & 1-3 Years & 126 & 38.0 \\
\hline & 4-6 Years & 135 & 40.7 \\
\hline & More than 6 years & 55 & 16.6 \\
\hline & Total & 332 & 100 \\
\hline \multirow{6}{*}{ Social Platforms } & Facebook & 137 & 41.3 \\
\hline & Twitter & 36 & 10.8 \\
\hline & Instagram & 34 & 10.2 \\
\hline & Others & 44 & 13.3 \\
\hline & More than one platform & 81 & 24.4 \\
\hline & Total & 332 & 100 \\
\hline
\end{tabular}

Source: developed by the researchers based on data analysis 


\subsection{Hypotheses Testing}

Simple linear regression was used to test the proposed eight hypotheses.

\subsubsection{First Hypothesis (H1)}

The first hypothesis suggests that Technological context has a high impact on SMEs' adoption of social media. The model summary is illustrated in Table 4.

Table 4: Model summary of $\mathrm{H} 1$

\begin{tabular}{|l|c|c|c|c|}
\hline Independent Variable & $\mathbf{r}$ & $\mathbf{R}^{\mathbf{2}}$ & Adjusted $\mathbf{R}^{\mathbf{2}}$ & $\begin{array}{c}\text { Std. Error of } \\
\text { the Estimate }\end{array}$ \\
\hline Technological Context & 0.104 & .011 & .008 & .520 \\
\hline \multicolumn{4}{l}{ Dependent Variable is Social media Adoption } \\
\hline
\end{tabular}

Source: developed by the researchers based on regression analysis

As shown in Table 4, Pearson correlation coefficient ( $r$ ) between the technological context and social media adoption is positive but very weak $(r=0.104)$, and the determination factor R2 is 0.011 indicating that technological context is responsible for $1.1 \%$ of the variation in social media adoption. The coefficients of simple linear regression are illustrated in Table 5 below.

Table 5: Simple linear regression coefficients of $\mathrm{H} 1$

\begin{tabular}{|c|c|c|c|c|c|c|}
\hline $\begin{array}{l}\text { Independent } \\
\text { Variable }\end{array}$ & \multicolumn{2}{|c|}{$\begin{array}{c}\text { Unstandardized } \\
\text { Coefficients B }\end{array}$} & $\begin{array}{l}\text { Standardized } \\
\text { Coefficients Beta }\end{array}$ & t-value & P-value & Decision \\
\hline \multirow{2}{*}{$\begin{array}{l}\text { Technological } \\
\text { Context }\end{array}$} & Constant & 3.551 & \multirow{2}{*}{0.104} & 14.218 & .000 & \multirow{2}{*}{$\begin{array}{c}\text { H1 } \\
\text { Not Supported }\end{array}$} \\
\hline & TechVar & .122 & & 1.895 & .059 & \\
\hline
\end{tabular}

*significant at $\alpha<0.05$; Dependent Variable is Social media Adoption

Source: developed by the researchers based on regression analysis

Table 5 shows that the technological context is insignificant since the $p$-value $=0.059$ which is greater than $(\alpha=0.05)$. Therefore, $\mathrm{H} 1$ is not supported by the data.

\subsubsection{Hypotheses (H2..H7)}

Hypotheses $\mathrm{H} 2 . . \mathrm{H} 7$ assume that the other six dependent constructs/variables have high impact on SMEs' adoption of social media. Table 6 presents the models' summaries of these hypotheses.

Table 6: Models' summaries of $\mathrm{H} 2 . . \mathrm{H} 7$

\begin{tabular}{|l|l|c|l|c|c|}
\hline Hypothesis & Independent Variable & $\mathbf{r}$ & $\mathbf{R}^{\mathbf{2}}$ & Adjusted $\mathbf{R}^{\mathbf{2}}$ & $\begin{array}{l}\text { Std. Error of } \\
\text { Estimate }\end{array}$ \\
\hline H2 & Organizational Context & 0.269 & .073 & .070 & .504 \\
\hline H3 & Environmental Context & 0.283 & .080 & .077 & .502 \\
\hline H4 & Perceived Usefulness & 0.350 & .122 & .120 & .489 \\
\hline H5 & Perceived Ease of Use & 0.306 & .093 & .091 & .498 \\
\hline H6 & Attitude toward Technology & 0.207 & .043 & .040 & .512 \\
\hline H7 & Ability to Control Technology & 0.363 & .132 & .129 & .487 \\
\hline Dependent Variable is Social media Adoption
\end{tabular}

Source: developed by the researchers based on regression analysis

Pearson correlation coefficients $(r$ ) of the other six independent variables are listed in Table 6; all of these values are positive reflecting a positive correlation between the examined variables and the dependent variable social media adoption. The values ranged from 0.207 for Attitude toward Technology to 0.363 for Ability to Control Technology. The coefficient of determination R2 of each of these constructs points that Organizational Context, Environmental Context, Perceived Usefulness, 
Perceived Ease of Use, Attitude toward Technology, Ability to Control Technology are responsible for the variation in social media adoption by $7.3 \%, 8 \%, 12.2 \%, 9.3 \%, 4.3 \%$ and $13.2 \%$ respectively.

The results of the simple linear regression analysis of these independent constructs/variables and social media adoption as dependent variable are presented in Table 7.

As shown in Table 7, all of hypotheses $\mathrm{H} 2$...H7 are supported by the data as the $\mathrm{p}$-value of each of the regression models is less than the significance level $(\alpha=0.05)$.

Table 7: Simple linear regression coefficients of $\mathrm{H} 2 . . \mathrm{H} 7$.

\begin{tabular}{|c|c|c|c|c|c|c|}
\hline Independent Variable & \multicolumn{2}{|c|}{$\begin{array}{l}\text { Unstandardized } \\
\text { Coefficients B }\end{array}$} & $\begin{array}{c}\text { Standardized } \\
\text { Coefficients } \\
\text { Beta }\end{array}$ & t-value & P-value & Decision \\
\hline \multirow{2}{*}{ Organizational Context } & Constant & 2.887 & \multirow{2}{*}{.269} & 12.846 & .000 & \multirow{2}{*}{$\begin{array}{c}\text { H2 } \\
\text { Supported }\end{array}$} \\
\hline & OrgVar & .286 & & 5.082 & $.000 *$ & \\
\hline \multirow{2}{*}{ Environmental Context } & Constant & 2.550 & \multirow{2}{*}{.283} & 9.226 & .000 & \multirow{2}{*}{$\begin{array}{c}\text { H3 } \\
\text { Supported }\end{array}$} \\
\hline & EnviVar & .374 & & 5.352 & $.000 *$ & \\
\hline \multirow{2}{*}{ Perceived Usefulness } & Constant & 2.551 & \multirow{2}{*}{.350} & 11.639 & .000 & \multirow{2}{*}{$\begin{array}{c}\text { H4 } \\
\text { Supported }\end{array}$} \\
\hline & PuseVar & .374 & & 6.771 & $.000^{*}$ & \\
\hline \multirow{2}{*}{ Perceived Ease of Use } & Constant & 2.720 & \multirow{2}{*}{.306} & 12.111 & .000 & \multirow{2}{*}{$\begin{array}{c}\text { H5 } \\
\text { Supported }\end{array}$} \\
\hline & PeaseVar & .322 & & 5.834 & $.000 *$ & \\
\hline \multirow{2}{*}{$\begin{array}{l}\text { Attitude toward } \\
\text { Technology }\end{array}$} & Constant & 3.161 & \multirow{2}{*}{.207} & 13.990 & .000 & \multirow{2}{*}{$\begin{array}{c}\text { H6 } \\
\text { Supported }\end{array}$} \\
\hline & AttiTechVar & .217 & & 3.839 & $.000 *$ & \\
\hline \multirow{2}{*}{$\begin{array}{l}\text { Ability to Control } \\
\text { Technology }\end{array}$} & Constant & 2.597 & \multirow{2}{*}{.363} & 12.810 & .000 & \multirow{2}{*}{$\begin{array}{c}\text { H7 } \\
\text { Supported }\end{array}$} \\
\hline & ContTechVar & .350 & & 7.086 & $.000 *$ & \\
\hline
\end{tabular}

Source: developed by the researchers based on regression analysis

\subsubsection{Hypothesis $\mathrm{H} 8$}

The eighth hypothesis ( $\mathrm{H} 8$ ) suggests that social media adoption by SME's has a positive impact on their performance. The model summary of this hypothesis is presented in Table 8.

Table 8: Model summary of $\mathrm{H} 8$

\begin{tabular}{|l|c|c|c|c|}
\hline Variable & $\mathbf{r}$ & $\mathbf{R}^{\mathbf{2}}$ & Adjusted $\mathbf{R}^{\mathbf{2}}$ & $\begin{array}{c}\text { Std. Error of the } \\
\text { Estimate }\end{array}$ \\
\hline Social media Adoption & 0.303 & .092 & .089 & .39484 \\
\hline
\end{tabular}

Pearson correlation coefficient $(r)$ between social media adoption and SME's performance is positive $(r=0.303)$, and the determination factor $R 2$ is 0.092 indicating that social media adoption is responsible for $9.2 \%$ of the variation in SME's.

The coefficients of simple linear regression are illustrated in Table 9 below. 
Table 9: Simple linear regression coefficients of $\mathrm{H} 8$

\begin{tabular}{|c|c|c|c|c|c|c|}
\hline Variable & \multicolumn{2}{|c|}{$\begin{array}{l}\text { Unstandardized } \\
\text { Coefficients B }\end{array}$} & $\begin{array}{c}\text { Standardized } \\
\text { Coefficients } \\
\text { Beta }\end{array}$ & $t$ & P-value & Decision \\
\hline \multirow{2}{*}{$\begin{array}{l}\text { Social media } \\
\text { Adoption }\end{array}$} & Constant & 3.073 & \multirow{2}{*}{.303} & 18.260 & .000 & \multirow{2}{*}{$\begin{array}{c}\text { H8 } \\
\text { Supported }\end{array}$} \\
\hline & SocAdpVar & .240 & & 5.771 & $.000 *$ & \\
\hline
\end{tabular}

Table 9 shows that social media adoption is significant since the $p$-value $=0.000$ which is less than $(\alpha=0.05)$. Therefore, $\mathrm{H} 8$ is supported by the data.

\section{Discussion}

The aim of this study is to explore those factors that might influence the adoption of social media by SMEs and its influence on performance. Seven constructs/variables of social media adoption were tested (technological context, organizational context, environmental context, perceived usefulness, perceived ease of use, attitude toward technology, and ability to control technology) to measure their influence on performance.

To reach this goal eight hypotheses were proposed. The first hypothesis was to study the influence of technological context on SMEs' adoption of social media. The results of statistical analysis showed no significant influence of this construct on social media adoption. Although this result contradicted the majority of previous studies, however it goes in line with the study of (Ahmad, Bakar, \&Ahmad ,2019) which has been conducted in a similar context of the current study. The appropriate explanation for this result is that the decision to adopt social media in SMEs is more influenced by internal factors than technological ones. Another possible reason is that the majority of the participant in this study are young people who are familiar with using social media, therefore the influence of technological factors are not significant. The second hypothesis examined the impact of the organizational context on SMEs' adoption of social media. The result indicated a significant impact of this construct on social media adoption. This is consistent with other studies (Ramdani et al , 2013; Ahani et al, 2017; AlBar, \&Hoque, 2019). The findings suggest that managers support appears to be a crucial factor in adopting social media in SMEs. IT adoption literature provided sufficient evidence that managers' support significantly influence adoption of social media and other ICT tools in SMEs (Hoque, Saif, AlBar, \&Bao, 2015). The third hypothesis studied the influence of environmental context on SMEs' adoption of social media. The result supported the claims that environmental factors are positively and significantly influencing social media adoption. These findings are in agreement with AlBar\&Hoque (2019) and Lin (2014). This implies that both competitive advantages and governmental legislations are important factors for SMEs to adopt social media in their business as it might help or hinder the adoption process (AlBar\&Hoque ,2019). For both hypotheses four and five that examined the impact of perceived usefulness and ease of use on SMEs' adoption of social media, the findings showed a positive and a significant influence of these two factors on the adoption of social media among SMEs in Palestine. These results are supported by previous studies (Venkatesh,et al, 2003: Awa, et al, 2015: Eze, et al, 2019).The findings is also consistent with TAM (Davis, 1989). Investigating the influence of attitude toward technology and the ability to control technology on SMEs' adoption of social media, the findings of hypotheses six and seven indicated the positive influence of the two factors on the adoption of social media by SMEs, the results are in line with existed studies (Kanchanatanee, Suwanno\&Jerernvongrayab, 2014). In Palestine, the managers of small businesses are usually the owners of the businesses, therefore their attitudes and their technological skills are very important in adopting of new technology.

Finally, the main objective of this study was to investigate the effect of social media adoption on SMEs performance. Consisting with most of the existing studies (Ainin et al, 2015: Yasa, et al, 2020: 
Qalati et al., 2021) the findings of hypothesis eight showed a significant positive impact of social media adoption by SMEs in Palestine on business performance.

The findings of this study can be utilized to by SMEs managers and the authorities to take the necessary procedures to facilitate the use of social media by SMEs. Initiatives by the government such as arrangement of regular meetings or conferences through the ministry of technology and communication to enhance the ICT knowledge among the owners and managers of SMEs could increase the adoption rate of ICT. In addition, SMEs should have clear strategy regarding the adoption of social media to improve their firms' performance (Alsulami et al 2016).

\section{Conclusion}

The study intended to identify those factors that are responsible for the adoption of social media at the small and medium enterprises in Palestine and to examine the potential effect of social media adoption on business performance. A combination of three models (TOE, TAM, TPB) was used for the proposed conceptual model. Online survey was used to collect the data from participants. A total of 332 valid questionnaires were analyzed using the simple regression analysis. The findings of hypotheses testing indicated that six of the seven hypotheses that examined the impact of independent constructs \variables on social media adoption were significant. Namely the variables were organizational context, environmental context, perceived usefulness, ease of use, attitude towards technology, and ability to control technology. For the seven hypothesis the result showed no significant impact of technological context on social media adoption. Regarding hypothesis eight the result revealed a significant influence of social media adoption on SMEs performance.

\section{References}

1. Abed, S. S. (2020). "Social commerce adoption using TOE framework: An empirical investigation of Saudi Arabian SMEs". International Journal of Information Management, Vol 53 pp:102-118.

2. Ahani, A., Rahim, N. Z. A., \& Nilashi, M. (2017). "Forecasting social CRM adoption in SMEs: A combined SEM-neural network method". Computers in Human Behavior, Vol 75 pp: 560-578.

3. Ahmad, S. Z., Bakar, A. R. A., \& Ahmad, N. (2019). Social media adoption and its impact on firm performance: the case of the UAE. International Journal of Entrepreneurial Behavior \& Research, Vol 25 No 1 pp: 85-111.

4. Ainin, S., Parveen, F., Moghavvemi, S., Jaafar, N. I., \& Shuib, N. L. M. (2015). "Factors influencing the use of social media by SMEs and its performance outcomes". Industrial Management \& Data Systems, Vol 115 No 3 pp: 570-588.

5. Alsulami, M., \& Shaikh, A. (2016). The Information-Seeking Problem in Human-Technology Interaction. International Journal Of Advanced Computer Science And Applications, 7(5), 584590.

6. Ajzen, I.(1988). Attitudes, personality and behavior. Chicago: Dorsey Press

7. AlBar, A. M., \& Hoque, M. R. (2019). "Factors affecting the adoption of information and communication technology in small and medium enterprises: A perspective from rural Saudi Arabia". Information Technology for Development, Vol 25 No 4 pp: 715-738.

8. Alfoqahaa, S. (2018)."Critical success factors of small and medium-sized enterprises in Palestine". Journal of Research in Marketing and Entrepreneurship, Vol 20 No 2 pp: 170-188.

9. Alshamaila, Y., Papagiannidis, S. and Li, F. (2013), "Cloud computing adoption by SMEs in the north east of England: A multi-perspective framework" Journal of Enterprise Information Management, Vol 26 No 3 pp: 250-275

10.Abdullatif, A. M., Shahzad, B., \& Hussain, A. (2017). Evolution of social media in scientific research: A0 case of technology and healthcare professionals in saudi universities. Journal of Medical Imaging and Health Informatics, 7(6), 1461-1468. 
11.AlSharji, A., Ahmad, S. Z., \& Bakar, A. R. A. (2018). "Understanding social media adoption in SME's". Journal of Entrepreneurship in Emerging Economies. Vol 10 No 2 pp:302-328.

12.Awa, H. O., Ojiabo, O. U., \& Emecheta, B. C. (2015). "Integrating TAM, TPB and TOE frameworks and expanding their characteristic constructs for e-commerce adoption by SMEs". Journal of Science \& Technology Policy Management Vol 6 No 1 pp: 76-94 .

13.Baker, R., \& White, K. (2010). "Predicting adolescents'use of social networking sites from an extended theory of planned behaviour perspective". Computers in Human Behavior, Vol 26 pp: 1591-1597

14.Bendoly, E., Citurs, A., \& Konsynski, B. (2007). "Internal infrastructural impacts on RFID perceptions and commitment: knowledge, operational procedures, and information-processing standards". Decision Sciences, Vol 38 No 3 pp: 423-449.

15.Borgman, H. P., Bahli, B., Heier, H., \& Schewski, F. (2013, January). "Cloudrise: exploring cloud computing adoption and governance with the TOE framework". In 2013 46th Hawaii international conference on system sciences (4425-4435). IEEE

16.Carter, L., \& Bélanger, F. (2005). "The utilization of e-government services: citizen trust, innovation and acceptance factors". Information systems journal, Vol 15 No 1 pp: 5-25.

17.Chong, A. Y. L., \& Chan, F. T. (2012). "Structural equation modeling for multi-stage analysis on Radio Frequency Identification (RFID) diffusion in the health care industry". Expert Systems with Applications, Vol 39 No 10 pp: 8645-8654

18.Curran, J. and Blackburn, R. (2001). Researching the Small Enterprise, Sage Awa, H. O.

19.Dahnil, M. I., Marzuki, K. M., Langgat, J., \& Fabeil, N. F. (2014). "Factors influencing SMEs adoption of social media marketing". Procedia-social and behavioral sciences, Vol 148, pp: 119126

20.Daniel, W. W., \& Cross, C. L. (2013). Biostatistics: A Foundation for Analysis in the Health Sciences. Hoboken, New Jersey: Wiley.

21.Davis, F. D. (1989). "Perceived usefulness, perceived ease of use, and user acceptance of information technology". MIS Quarterly, Vol 13 No 3 pp: 319-340.

22.Delone, W. H., \& McLean, E. R. (2003). "The DeLone and McLean model of information systems success: a ten-year update". Journal of management information systems, Vol 19 No 4 pp: 9-30

23.Eze, S. C., Chinedu-Eze, V. C., \& Bello, A. O. (2019). "Determinants of dynamic process of emerging ICT adoption in SMEs-actor network theory perspective". Journal of Science and Technology Policy Management Vol 10 No 1 pp: 2-34.

24.Fishbein, M., \& Ajzen, I. (1975). Belief, attitude, intention and behavior: An introduction to theory and research. Reading, MA: Addison-Wesley.

25.Guha, S., Harrigan, P., \& Soutar, G. (2018). "Linking social media to customer relationship management (CRM): A qualitative study on SMEs". Journal of Small Business \& Entrepreneurship, Vol 30 No 3 pp: 193-214

26. Hansson, L., Wrangmo, S. and Søilen, K.S. (2013). "Optimal ways for companies to use Facebook as a marketing channel". Journal of Information, Communication and Ethics in Society, Vol 11 No 2 pp: 112-126.

27.Hoque, A.S.M.M., Awang, Z., \& Gwadabe, U.M. (2018g). "The Effect of Entrepreneurial Marketing on Bangladeshi SME performance and the Role of Organizational Culture: A Structural Equation Modelling". Journal of Management and Operation Research, Vol 1 pp: 1-21.

28.Hoque, R., Saif, A. N. M., AlBar, A. M., \& Bao, Y. (2015). "Adoption of information and communication technology for development $A$ case study of small and medium enterprises in Bangladesh". Information Development, Vol 32 No 4 pp: 986-1000.

29.Kanchanatanee, K., Suwanno, N. and Jarernvongrayab, A., (2014). "Factors affecting the intention to use E-marketing of small and medium sized businesses in the three southern border 
provinces of Thailand". International Journal of Business and Social Science, Vol 5 No 6 pp: 139 144.

30.Kaplan, Andreas M., and Michael Haenlein (2010). "Users of the world, unite! The challenges and opportunities of Social Media" Business horizons Vol 53 No 1 pp: 59-68

31.Kim, W.G., Li, J.J. and Brymer, R.A., (2016). "The impact of social media reviews on restaurant performance: The moderating role of excellence certificate". International Journal of Hospitality Management, Vol 55, pp:41-51.

32.Li, X., Troutt, M. D., Brandyberry, A., \& Wang, T. (2011). "Decision factors for the adoption and continued use of online direct sales channels among SMEs". Journal of the Association for Information Systems, Vol 12 No 1 pp: 1-32

33.Lin, H.F. (2014), "Understanding the determinants of electronic supply chain management system adoption: Using the technology-organization-environment framework", Technological Forecasting and Social Change, Vol. 86 No. C, pp. 80-92.

34.Low, C., Chen, $\mathrm{Y}$ and $\mathrm{Wu}, \mathrm{M}$. (2011), "Understanding the determinants of cloud computing adoption", Industrial Management and Data Systems, Vol 111 No 7 pp: 1006-1023.

35.Namankani, H., Moxham, C., \& Tickle, M. (2016, September). "A conceptual review of social media adoption in SMEs". In Conference on e-Business, e-Services and e-Society, pp: 240-250. Springer, Cham

36.Nunnaly, J. (1978). Psychometric theory. New York: McGraw-Hill

37.Ojiabo, O. U., \& Emecheta, B. C. (2015). "Integrating TAM, TPB and TOE frameworks and expanding their characteristic constructs for e-commerce adoption by SMEs". Journal of Science \& Technology Policy Management, pp:571-588.

38.Oliveira, T., Thomas, M. and Espadanal, M. (2014). "Assessing the determinants of cloud computing adoption: An analysis of the manufacturing and services sectors". Information and Management, Vol 51 No 5 pp: 497-510

39.Ooi, K. B., Sim, J. J., Yew, K. T., \& Lin, B. (2011). "Exploring factors influencing consumers' behavioral intention to adopt broadband in Malaysia". Computers in Human Behavior, Vol 27 No 3 pp: 1168-1178.

40.Ordanini, A. (2006). Information technology and small businesses: Antecedents and consequences of technology adoption. Edward Elgar Publishing

41.Öztamur, D., \& Karakadılar, i. S. (2014). "Exploring the role of social media for SMEs: as a new marketing strategy tool for the firm performance perspective". Procedia-Social and behavioral sciences, Vol 150 pp: 511-520

42.Premkumar, G. (2003). "A meta-analysis of research on information technology implementation in small business". Journal of Organizational Computing and Electronic Commerce, Vol 13 No 2, pp: 91-121

43.Qalati, S. A., Yuan, L. W., Khan, M. A. S., \& Anwar, F. (2021). "A mediated model on the adoption of social media and SMEs' performance in developing countries". Technology in Society, Vol 64, 101513

44.Qureshi, S., \& York, A. S. (2008, January). "Information technology adoption by small businesses in minority and ethnic communities". In Proceedings of the 41st ual Hawaii International Conference on System Sciences (HICSS 2008) (pp. 447-447). IEEE

45.Ramdani, B., Chevers, D., \& Williams, D. A. (2013). "SMEs' adoption of enterprise applications: A technology-organisation-environment model". Journal of Small Business and Enterprise Development, Vol 20 No 4 pp: 735-753

46.Rogers, E. M. (2010). Diffusion of innovations. Simon and Schuster. 
47.Salam, S., \& Hoque, A. S. M. M. (2019). "The Role of Social Media and Effect of Relationship Marketing on SME Performance in Bangladesh: Multi-Group CFA". Asian People Journal (APJ), Vol 2 No 1 pp: 12-31

48.Siamagka, N. T., Christodoulides, G., Michaelidou, N., \& Valvi, A. (2015). "Determinants of social media adoption by B2B organizations". Industrial Marketing Management, Vol 51 pp: 89-99

49.Sophonthummapharn, K. (2009). "The adoption of techno-relationship innovations: A framework for electronic customer relationship management". Marketing Intelligence \& Planning, Vol 27 No 3 pp: 380-412.

50.Talukder, M., Quazi, A., \& Djatikusumo, D. (2013). "Impact of social influence on individuals'adoption of social networks in SMES". Journal of Computer Science, Vol 9 No 12 pp: 1686-1694

51.The Palestinian Central Bureau of Statistics, (2018). General Census of Population, Housing and Establishments 2017, Final Results - Establishments Report. Ramallah - Palestine

52.Venkatesh, V., M. G. Morris, G. B. Davis, and F. D. Davis (2003). "User Acceptance of Information Technology: Toward a Unified View". MIS Quarterly, Vol 27 No 3 pp: 425-478

53.W1: Digital 2020. Available. Last access 1-12-2020. https://datareportal.com/reports/digital2020-palestine.

54.Wamba, S. F., \& Carter, L. (2016). "Social media tools adoption and use by SMEs: An empirical study". Social media and Networking: Concepts, methodologies, tools, and applications, pp: 791806. IGI Global

55.Watson, J., 2012. "Networking: Gender differences and the association with firm performance". International Small Business Journal, Vol 30 No 5 pp: 536-558.

56.Yasa, N. N. K., Adnyani, I. G. A. D., \& Rahmayanti, P. L. D. (2020). "The influence of social media usage on the perceived business value and its impact on business performance of silver craft SME's in Celuk village, Gianyar-Bali". Academy of Strategic Management Journal, Vol 19 No 1 pp: 1-10.

57.Yu, W., Ramanathan, R. and Nath, P., 2017. "Environmental pressures and performance: An analysis of the roles of environmental innovation strategy and marketing capability". Technological Forecasting and Social Change, Vol 117, pp: 160-169.

58.Zhu, G., Sangwan, S., \& Lu, T. J. (2010). "A new theoretical framework of technology acceptance and empirical investigation on self-efficacy-based value adoption model". Nankai Business Review International, 1(4), 345-372. 